\title{
Prevalence and potential risk factors of hypocalcaemia in dairy cows during transition period at Northern Egypt
}

Hala Abdelmenem Rizk Saed ${ }^{1}$, Hussam Mohamed Mohamed Ibrahim ${ }^{2 *}$, Sabry Ahmed El-khodery², Mohamed Ahmed Youssef ${ }^{2}$

${ }^{1}$ Veterinary Teaching Hospital, Faculty of Veterinary Medicine, Mansoura University, Mansoura 35516, Egypt

${ }^{2}$ Department of Internal Medicine and Infectious Diseases, Faculty of Veterinary Medicine, Mansoura University, Mansoura 35516, Egypt

\section{ARTICLE HISTORY}

Received: 27.02 .2020

Revised: 18.03 .2020

Accepted: 19.03 .2020

Address correspondence to H.M.M. Ibrahim; Tel: +2-050-2214233;

E-mail: hussam-habosha@mans.edu.eg; ORCID: 0000-0002-3731-4586

\section{ABSTRACT}

Objective: To identify the most prevalent diseases of transition period in dairy cows and to highlight potential risk factors that are supposed to play a critical role in the prevalence of hypocalcaemia.

Design: Case-control study

Animals: 179 transition dairy cows belonged to five farms.

Procedures: In the selected dairy cows, both clinical examination and serum analysis were used as a key to diagnose the transition period disorders. The serum analytes were measured, including calcium (Ca), inorganic phosphorous (P), magnesium (Mg), parathyroid hormone (PTH), glucose, potassium (K), sodium (Na) and chloride $(\mathrm{Cl})$ and then their cutoff points were set. A questionnaire was constructed to identify the possible risk factors associated with hypocalcaemia on both the farm and cow level.

Results: In this study, the prevalence of hypocalcaemia, hypophosphatemia, hypomagnesaemia, hypoglycemia, hypokalemia, clinical ketosis, and abomasal displacement was 48.04\%, 40.22\%, 33.52\%, 29.05\%, 58.1\%, 5.59\%, and 1.12\%, respectively. Furthermore, the prevalence of post parturient septic metritis, retained placenta, and clinical mastitis was $26.81 \%, 23.46 \%, 18.99 \%$, respectively. On farm level, the type of the diet, housing criteria, and periodical monitoring of metabolic profile test significantly $(P<0.05)$ affected the incidence of hypocalcaemia. On cow level, age, parity, body condition score, stage of transition period, daily milk yield, and history of presence of previous transition period disorders had a significant $(P<0.05)$ effect on the occurrence of hypocalcaemia. Moreover, the occurrence of hypocalcaemia in the studied dairy cows was significantly correlated with high level of each of PTH $(P=0.006)$, glucose $(P=0.001), \mathrm{K}(P=0.019)$, $\mathrm{Na}(P=0.001)$, and $\mathrm{Cl}(P=0.045)$.

Conclusion and clinical relevance: The results of the current study pointed the importance of regular monitoring of the transition period disorders in dairy cows, besides the identification of the potential risks and consequences of hypocalcaemia in an attempt to establish control measures for them, which in turn will increase the profitability of dairy herds.

Keywords: Risk factors, Hypocalcaemia, Transition period, Dairy Cattle, Northern Egypt.

\section{INRODUCTION}

Perhaps one of the most challenging areas for both producers and scientists has been addressing the health issues during cows' transition periods. From the reproductive performance perspective, transition periods are the most critical times spent by dairy cows. During which, biological adjustments to cope with the dramatic increase in production are occurred. The pronounced goal of proper nutritional management during this time frame is surely to maintain the respective metabolic adaptations. [1]. Transition period has been widely defined as the period including the last three weeks prior to expected date of delivery (EDD) until three weeks after parturition. At which, cows undergo extensive metabolic alternations of glucose, fatty acids, vitamins and mineral metabolism to escort the coming fetus and the onset of lactation [2].
Calcium (Ca), the magic macro-element, is the most abundant mineral in the body. It is an imperative constituent of, and is necessary for, normal physiological processes in the body including normal nerve function, muscle contractions and milk production. Additionally, $\mathrm{Ca}$ exhibits several signaling processes in immune cells as it directs the production of several inflammatory cytokines [3]. Ensuring a normal level of plasma $\mathrm{Ca}$ is necessary to establish its missions properly and to protect cows from the risk of hypocalcaemia and its allied consequences [4].

Inorganic phosphorus (P) also displays a wide variety of physiological functions involving other minerals metabolism and bony skeleton development. Besides, it shares in formation of many important molecules as nucleic acids and energy molecules (ATP), and consequently has widespread cellular effects [5]. 
Magnesium (Mg) is the second most abundant intracellular element in the body. similar to $\mathrm{Ca}, \mathrm{Mg}$ is found mainly bound in the bony skeleton [6]. It plays an important role in nerve transmission process. Additionally, it is essential for normal production and function of the parathyroid hormone. Hence it is regarded as a chief player in the metabolic profile of transition dairy cows [4].

The Parathyroid hormone (PTH) is a single-chain polypeptide, consisted of 84 amino acids, secreted by the parathyroid gland. It is an essential constituent of the normal Ca homeostatic mechanism displayed by the 1,25 dihydroxy vitamin $D_{3}$, where both hormones are stimulated together during episodes of hypocalcaemia.

Glucose is the major fuel supply that supports the developing fetus as well as it is used by the mammary gland for milk production. Concentration of plasma glucose remains relatively steady or just increases slightly during the preparturient period [7]. Previous data recorded a dramatic increase in its plasma level at the calving time and then a decrease soon after calving [8-10].

The serum electrolytes, including potassium (K), sodium $(\mathrm{Na})$, and chloride $(\mathrm{Cl})$, play also a crucial role in dairy cows, especially just after the parturition due to the high loss of these elements during milk production [11]. The levels serum electrolytes are found to be significantly higher during the late pregnancy as compared with the calving time and the post-parturient period [12-14].

The selected serum parameters interact together, being a part of several endogenous mechanisms that affect greatly on the incidence of metabolic and, to some extent, inflammatory disorders of dairy cows. Despite all the exerted metabolic and managemental modulations during the transition period, metabolic and other health problems are centered disproportionately in this relatively short period, making it an interesting time to follow up [1].

Hypocalcaemia is a term applied to cows whose blood $\mathrm{Ca}$ concentration is $\leq 2.0 \mathrm{mmol} / \mathrm{l}$. It is considered the most important macro-mineral metabolic disorder in transition dairy cows. An imbalance between $\mathrm{Ca}$ output in milk and $\mathrm{Ca}$ influx to the extracellular pool from bone and intestine is the central core for occurrence of such metabolic disorder [6]. On a broad scope, a meta-analysis, enrolled 135 studies, has showed that incidence of hypocalcaemia could reach up to $83 \%$ on a herd level [15]. Surely, this high percentage reveals a great concern to point up the risk factors implicated in development of such disease.

The occurrence of hypocalcaemia in dairy cows is largely related to the increased prevalence of other various transition period disorders. Dairy cows with hypocalcaemia are, up to eight times, more likely to develop mastitis in the following lactation, are three times more likely to develop dystocia and two to four times more likely to develop displaced abomasum [16]. From this point, the objectives of the current study were to investigate the prevalence of metabolic disorders and other health troubles, which may occur during the transition period. Furthermore, this study will throw the light on the potential risk factors associated with hypocalcaemia in dairy cows in Northern Egypt.

\section{MATERIALS AND METHODS}

\subsection{Animals}

A total of 179 transition dairy cows, belonged to five different farms, were investigated. Of all, five apparently healthy cows were selected randomly per each investigated farm (number per farm $=25$ ) and served as control group for the study. All cases were studied during the transition period; 3 weeks prior to the EDD until 3 weeks post-partum [1]. The study was conducted during the period of November, 2016 and March, 2017 in Dakahlia and Damietta governorates, Egypt. All of the studied dairy cows did not receive any form of medication prior to clinical diagnosis and blood sampling. Comprehensive data related to complete case history, clinical findings, and medical records for each cow were taken by asking farm personnel and veterinarians. The anamnesis involved in this study included farm database, besides the following items related to the studied cows; breed, age, parity number, body condition score (BCS), stage of transition period, daily milk yield, and history of previous transition period disorders. All procedures were performed in accordance with the guidelines of Mansoura University, Egypt and approved by the Animal welfare and Ethical Committee, Faculty of Veterinary Medicine, Mansoura University.

\subsection{Clinical examination}

Detailed clinical examination of the dairy cows under investigation was performed. The examination was directed to detect evidence of systemic illness (dullness, fever, tachycardia, appetite disturbances, ruminal stasis, and recumbency). Cows were assumed to suffer metabolic disorders on the basis of clinical signs reported by Constable et al. [6], and further confirmed by biochemical analysis of serum. Dairy cows were diagnosed to be affected with clinical post-parturient septic metritis based on the criteria of clinical examination, vaginal discharges, and rectal palpat-ion of the uterus [17]. Dairy cows were regarded to have retained placenta when they failed to expel the fetal membranes for more than 12 hours following parturition. Clinical mastitis was diagnosed in the studied dairy cows by clinical examination, along with local physical examination of the udder via inspection and palpation of the quarters as well as palpation of the supra-mammary lymph nodes for evidence of cardinal signs of inflammation (hotness, pain sensation and swelling) or evidence of fibrosis or atrophy. Moreover, visual examination of the milk per each cow with mastitis was done using Strip-Cup test for detection of any abnormalities, including milk clots, flakes, high viscosity, pus, bloody or watery secretions [11].

\subsection{Blood Sampling}

A peripheral blood sample $(5 \mathrm{ml})$ was collected in plain tubes without anticoagulant via jugular vein puncture from each investigated dairy cow. The collected samples immediately centrifuged for separation of serum, which was kept frozen at $-80^{\circ} \mathrm{C}$ for subsequent biochemical analysis. 


\subsection{Biochemical analysis}

The level of the PTH in the serum was assessed by electro-chemiluminescence assay using COBAS apparatus e411, Roche Diagnostics, Germany. The level of each of $\mathrm{Ca}$, $\mathrm{Ph}, \mathrm{Mg}, \mathrm{Na}, \mathrm{K}$ and $\mathrm{Cl}$ in serum was measured spectrophotometrically using commercial kits (Human Gesellschaft Fur Biochemica und Diagnostica $\mathrm{mbH}$, Germany). Serum glucose level was estimated by colorimetric method using Spinreact kits, S.A/ S.A.U. For all measured parameters, the detection methodology was conducted according to the information supplied by the manufacturer.

\subsection{Risk factors investigation}

On the farm level, the potential risk factors, including type of the diet, mineral supplementation, housing criteria, periodical monitoring of metabolic profile test, and the geographic soil type were basically recorded. Moreover, on the cow level, potential risk factors have been categorized into animal risk factors and biochemical risk factors. The animal risk factors involved the following items; breed, age, parity number, BCS, stage of transition period, daily milk yield, and history of previous transition period disorders. The biochemical risk factors included the level of each of $\mathrm{p}, \mathrm{Mg}$, PTH, glucose, $\mathrm{K}, \mathrm{Na}$, and $\mathrm{Cl}$. The criteria of the studied categorical risk factors were given scores for further statistical analysis. However, the biochemical risk factors were categorized into normal and abnormal based on the estimated cutoff point of each of them and also scored for further statistical analysis. Furthermore, the association between the biochemical values of the metabolic profile test for each studied cow and the level of Ca was also considered in this study.

\subsection{Statistical analysis}

Data analysis was performed using Statistical Software Program (SPSS for Windows, Version 21.0, SPSS Inc., USA). To assess the prevalence of various transition disorders in dairy cows, descriptive statistics of the diagnosed disorders on the selected farms level were performed and presented. The cutoff point of each assessed serum biochemical parameters was determined using the ROC curve analysis. For evaluation of the association between the possible risk factors that are supposed to play a vital role and the occurrence of hypocalcaemia in dairy cows, on farm and cow level, a Chisquare test was performed. The results were presented as $P$ value, Odds ratio (OR), and Confidence Interval $95 \%$ (CI 95\%). The results were considered to be significant at $P<0.05$.

\section{RESULTS}

Based on the case history, clinical examination, and biochemical analysis, numerous metabolic disorders as well as other inflammatory conditions were diagnosed. As a general result, the occurrence of multiple events in individual cows had the largest share in the existing study. Most cases suffered metabolic disorders, which seemed clinically silent and only diagnosed by the serum analysis based on the estimated cutoff points. With regard to the prevalence of the diagnosed disorders in a total number of 179 studied dairy cows during transition period, described in order per each serum parameter, hypocalcaemia was diagnosed, with cutoff point of $\mathrm{Ca}<2.24 \mathrm{mmol} / \mathrm{L}$, in 86 cows $(48.04 \%)$. It should be noted that $46 / 86$ hypocalcaemic cows, with a percentage of $53.5 \%$, had other health disorders. Hypophosphatemia was identified, with cutoff point of $P<1.6 \mathrm{mmol} / \mathrm{L}$, in 72 cows (40.22\%), while hypomagnesaemia was recognized, with cutoff point of $\mathrm{Mg}<0.88 \mathrm{mmol} / \mathrm{L}$, in 60 cows (33.52\%). At the glucose cutoff point $<2.62 \mathrm{mmol} / \mathrm{L}$, hypoglycemia was observed in 52 cows (29.05\%), and clinical ketosis was detected in $10 / 179$ cows (5.59\%). Hypokalemia, with cutoff point of $\mathrm{K}<4.25 \mathrm{mmol} / \mathrm{L}$, was exhibited by 104 cows (58.1\%). Only 2 cows were diagnosed as displaced abomasum condition (1.12\%). Post parturient septic metritis was recorded in 48 cows (26.81\%), retained fetal membranes was identified in 42 cows $(23.46 \%)$, and clinical mastitis was diagnosed in 34 cows (18.99\%) (Table 1).

On farm level, the distribution and Chi-square analysis for the risk factors that are assumed to play a role in the incidence of hypocalcemia in dairy cattle are summarized in Table 2. The type of the diet regimen had a significant effect on the incidence rate of hypocalcemia in the studied dairy cows, as the total mixed ration feeding system (TMR) was significantly associated with a higher incidence of such disorder (88.4\%) compared to the NRC recommendations $(11.6 \%)(P$-value $=0.008$, OR: $0.339, \mathrm{Cl} 95 \%$ : $0.152-0.755)$. However, addition of mineral supplements to the diet didn't affect the incidence rate of the condition in the dairy cows under investigation ( $P$-value $=0.108$, OR: $570, \mathrm{Cl} 95 \%: 0.300$ - 1.081). Housing criteria had a significant impact on the incidence rate of hypocalcemia in the selected dairy cows, as the indoor housing system had the greatest impact on the incidence rate of this disorder (88.4\%) in comparison with the semi-open housing system $(11.6 \%)(P$-value $=0.008, \mathrm{OR}$ : $0.339, \mathrm{Cl} 95 \%$ : $0.152-0.755)$. In addition, farms that follow an organized plan for assessing the feed intake requirements and early detection of metabolic disorders, which are similar to the periodic application of the metabolic profile test, had a significant lower incidence of hypocalcaemia (88.4\%) than the other farms (11.6\%) ( $P$-value $=0.008$, OR: $0.339, \mathrm{Cl} 95 \%$ : $0.152-0.755)$. However, the type of geographical soil in which the farms are located didn't affect the incidence rate of hypocalcemia in the examined dairy cows $(P$-value $=0.630$, OR: 0.765, CI 95\%: $0.292-2.001$ ).

On animal level, the distribution and Chi-square analysis the presumed risk factors for the incidence of hypocalcemia in dairy cattle are summarized (Table 3 ). The breed had no significant effect on the incidence rate of hypocalcemia in the studied cows ( $P$-value $=0.455$, OR: $0.788, \mathrm{Cl} 95 \%: 0.421-$ 1.474). On the other hand, age, parity number, BCS, stage of transition period, daily milk yield, and previous transition period disorders had a significant impact on the incidence of the hypocalcemia in the selected dairy cattle. Cows aged $>5$ up to 8 years old ( $88.4 \%)$ were at a higher risk than those aged $\leq 5$ years old $(11.6 \%)(P$-value $=0.001$, OR: $11.000, \mathrm{Cl} 95 \%$ : 5.051 - 23.954). Furthermore, dairy cows with multiple parities, $>3$ up to 7 times, were the most affected group $(72.1 \%)$ compared to those with lower parity number, $\leq 3$ 
times ( $P$-value $=0.001$, OR: 7.427, Cl 95\%: $3.832-14.393)$. All examined dairy cows with $\mathrm{BCS} \geq 3.5$ were significantly affected with hypocalcaemia in comparison with those with BCS $<3.5$ ( $P$-value $=0.001$, OR: 0.456, Cl 95\%: $0.384-0.540)$. The stage of transition period had a significant effect on the incidence rate of hypocalcemia in the examined dairy cows, as at the calving day till 3 weeks post-partum was the significant time zone for its occurrence $(93 \%)$ compared to the period of 3 weeks prior to the EDD $(7 \%)(P$-value $=0.001$, OR: 5.455, Cl 95\%: 2.125 - 14.002). Likewise, the daily milk yield significantly affected the incidence of hypocalcemia in dairy cows under investigation. Cows that produce $\geq 20 \mathrm{~kg}$ milk per day $(60.5 \%)$ were significantly affected than those that produce $<20 \mathrm{~kg}$ milk per day $(39.5 \%)(P$-value $=0.001$, OR: $0.116, \mathrm{Cl} 95 \%$ : 0.057 - 0.237). Similarly, history of previous transition period disorders was significantly associated with a higher incidence of hypocalcemia in the selected cows, as $60.5 \%$ of the hypocalcaemic cases experienced health problems during the previous transition periods ( $P$-value $=0.001 ;$ OR: $0.318, \mathrm{Cl} 95 \%$ : $0.159-0.634)$.

The correlation between values of serum biochemical parameters and hypocalcemia in the examined dairy cows are summarized in Table 4. There was a non-significant association between the level of both $\mathrm{P}$ and $\mathrm{Mg}$ and occurrence of hypocalcemia ( $P$-value $=0.720$, OR: $1.129, \mathrm{Cl}$ 95\%: $0.582-2.191)$ and $(P$-value $=0.113$, OR: $1.633, \mathrm{Cl} 95 \%$ : 0.888 - 3.003), respectively. However, the PTH was significantly increased in dairy cows with hypocalcemia where, $69.8 \%$ of hypocalcaemic cases had a serum PTH level $\geq 3.18 \mathrm{pmol} / \mathrm{L}(P$-value $=0.006, \mathrm{OR}: 2.358, \mathrm{Cl} 95 \%: 1.276-$ 4.357). Likewise, hyperglycemic state in the examined cows was significantly associated with hypocalcaemic condition, where $81.4 \%$ of hypocalcaemic cows had a serum glucose level $\geq 2.62 \mathrm{mmol} / \mathrm{L}$ ( $P$-value $=0.001$, OR: 5.797, Cl 95\%: 2.934 - 11.451). Hypokalemia was significantly associated with hypocalcaemia in the studied dairy cows, where $69.8 \%$ of hypocalcaemic cows had a serum $\mathrm{K}$ level $<4.25 \mathrm{mmol} / \mathrm{L}(P$ value $=0.019$, OR: $0.483, \mathrm{Cl} 95 \%$ : $0.261-0.892$ ). Also, high level of both $\mathrm{Na}$ and $\mathrm{Cl}$ in the serum of studied cows was significantly associated with hypocalcemic state $(P$-value $=$ 0.001, OR: $2.672, \mathrm{Cl} 95 \%: 1.460-4.890)$ and $(P$-value $=0.045$, OR: 0.547, Cl 95\%: $0.302-0.990)$, respectively.

\section{DISCUSSION}

So far, transition period continues to be an influential time zone on cow's health that holds the matter of the current and future production in dairy cattle industry all over the world. The ability to identify the prevalent disorders of transition period in cows leads to prompt intervention and therefore prevention of these conditions. In this study, the incidence of hypocalcaemia among the investigated dairy cows was $48.04 \%$. Absolutely, $\mathrm{Ca}$ is an integral player in transition periods of cows and its circulating level is highly changeable during this period. Yves et al. [18] have clarified that cows, during the whole pregnancy, receive an adequate supply of vitamin D and Ca in diets, where farmers are much aware of this. This pattern of feeding is somewhat suppressive for the activation of endogenous Ca homeostasis in the body, where the calcitonin, a bone resorption blocking hormone, is the predominant. At the onset of lactation, cows endure a rapid and severe loss of $\mathrm{Ca}$ in colostrum that may reach a nine fold increase than that present in plasma [6]. Unfortunately, at this time, the genetic and hormonal machinery systems for Ca homeostasis are switched off, and need some time to be activated. Similar results were recorded before in a study performed by Houe et al. [19], where the incidence rate of hypocalcaemia in individual herds reached up to $34 \%$, with average of $5-10 \%$ of individual cows. Moreover, Roche [20] reported that the incidence of subclinical hypocalcaemia was 33\% in grazing New Zealand dairy cows, while the incidence of clinical hypocalcemia was $5 \%$ only. The highest prevalence of clinical hypocalcemia was recorded by the Dairy Herd Health Group at UCD with incidence rate of $50 \%$ in individual dairy herds [16].

Hypophosphatemia was recorded in $40.22 \%$ of the studied dairy cows. Valk et al. [21] reported that, the concentration of $P$, which is released into milk, is relatively constant and directly proportional to the degree of production of phospholipids in milk. As milk production increases, more $\mathrm{P}$ is absorbed from the gut, little is excreted in feces, and much is retained by the kidneys. Similar to K, when the diet intake is diminished during the transition period, less $P$ is available for the intestinal absorption. However, Abd-Allah and Bakr [13] recorded a non-significant variation in $\mathrm{P}$ level during the studied transition period.

Hypomagnesaemia showed a relatively high incidence rate (33.52\%) among the investigated metabolic disorders in dairy cows under investigation. The exact cause of hypomagnesaemia in cows is a primary deficiency of $\mathrm{Mg}$ in the diet. Mg absorption from the gut depends mainly on the $\mathrm{Na} / \mathrm{K}-\mathrm{ATPase}$ pump [6], where a perfect result is realized by a $\mathrm{Na}$ K ratio equal 5:1. Hypomagnesaemia appears mainly when cows' diet is changed promptly from mixed dry feed to the rapidly growing, lush, grasses deficient in $\mathrm{Mg}$, rich in $\mathrm{K}$ and nitrogen levels [22]. Intracellular $\mathrm{Mg}$ is necessary for several enzymes that regulate the body metabolism. However, the extracellular $\mathrm{Mg}$ is only $1 \%$ of the total $\mathrm{Mg}$ concentration in the body, where it plays a crucial role for normal nerve transmission processes.

Hypokalemia was expressed by $58.1 \%$ of the studied cows which may be due to a number of important factors. It was diagnosed only through the serum biochemical analysis and did not express any clinical signs. Only $10 \%$ of the total $\mathrm{K}$ in the body present in the extra-cellular fluid, while the plasma level represent only $0.4 \%$ of the total $\mathrm{K}$ in the body. This low reserve of $\mathrm{K}$ makes it highly dependent on its source in the diet. 
Table 1. Distribution of the most common disorders that occur during transition period in dairy cows at Northern Egypt

\begin{tabular}{|c|c|c|c|c|c|c|}
\hline Disorders & $\begin{array}{l}\text { Farm } 1 \\
(n=19)\end{array}$ & $\begin{array}{l}\text { Farm 2 } \\
(n=21)\end{array}$ & $\begin{array}{l}\text { Farm } 3 \\
(n=35)\end{array}$ & $\begin{array}{l}\text { Farm } 4 \\
(n=17)\end{array}$ & $\begin{array}{l}\text { Farm } 5 \\
(n=87)\end{array}$ & $\begin{array}{c}\text { Total } \\
(n=179)\end{array}$ \\
\hline Hypocalcaemia & 8 & 12 & 24 & 2 & 40 & 86 \\
\hline Hypophosphatemia & 2 & 6 & 10 & 4 & 50 & 72 \\
\hline Hypomagnesaemia & 4 & 4 & 8 & 8 & 36 & 60 \\
\hline Hypoglycemia & 2 & 2 & 2 & 8 & 38 & 52 \\
\hline Hypokalemia & 14 & 12 & 20 & 6 & 52 & 104 \\
\hline Clinical ketosis & 0 & 0 & 2 & 0 & 8 & 10 \\
\hline Abomasal displacement & 0 & 0 & 0 & 1 & 1 & 2 \\
\hline Post-parturient septic metritis & 12 & 12 & 18 & 2 & 4 & 48 \\
\hline Retained placenta & 2 & 2 & 2 & 2 & 34 & 42 \\
\hline Clinical mastitis & 0 & 20 & 0 & 6 & 8 & 34 \\
\hline
\end{tabular}

Table 2. Categorization of dairy cows as normocalcaemic or hypocalcemic with respect to different risk factors on farm level

\begin{tabular}{|c|c|c|c|c|c|}
\hline \multirow[b]{2}{*}{ Variables } & \multicolumn{2}{|c|}{ Calcium level } & \multirow[b]{2}{*}{ P-value } & \multirow[b]{2}{*}{ Odds ratio } & \multirow[b]{2}{*}{ Cl $95 \%$} \\
\hline & $\begin{array}{l}\text { Normocalcaemic } \\
\qquad(n=93)\end{array}$ & $\begin{array}{l}\text { Hypocalcaemic } \\
\qquad(n=86)\end{array}$ & & & \\
\hline Diet & & & 0.008 & 0.339 & $0.152-0.755$ \\
\hline NRC & $26(27.9 \%)$ & $10(11.6 \%)$ & & & \\
\hline TMR & $67(72.1 \%)$ & $76(88.4 \%)$ & & & \\
\hline Mineral supplementation & & & 0.108 & 0.570 & $0.300-1.081$ \\
\hline Yes & $35(37.6 \%)$ & $22(25.6 \%)$ & & & \\
\hline No & $58(62.4 \%)$ & $64(74.4 \%)$ & & & \\
\hline Housing criteria & & & 0.008 & 0.339 & $0.152-0.755$ \\
\hline Semi-open system & $26(27.9 \%)$ & $10(11.6 \%)$ & & & \\
\hline Indoor system & $67(72.1 \%)$ & $76(88.4 \%)$ & & & \\
\hline \multicolumn{2}{|c|}{ Periodical monitoring of metabolic profile test } & & 0.008 & 0.339 & $0.152-0.755$ \\
\hline Yes & $26(27.9 \%)$ & $10(11.6 \%)$ & & & \\
\hline No & $67(72.1 \%)$ & $76(88.4 \%)$ & & & \\
\hline Geographic soil type & & & 0.630 & 0.765 & $0.292-2.001$ \\
\hline Sandy soil & $11(11.8 \%)$ & $8(9.3 \%)$ & & & \\
\hline Muddy soil & 82 (88.2 \%) & 78 (90.7 \%) & & & \\
\hline
\end{tabular}

During spring and winter seasons in Egypt, the exact time zone of this study, farmers mainly depend on typical forage as a based diet, which is relatively high in $\mathrm{K}$ content and as a consequence, the renal $\mathrm{K}$ excretion is increased [23]. During the transition period, cows endure an acute phase response that causes a reduction in feed intake [24]. This will contribute greatly to the development of a condition, where the renal system will take will take some time to work to stabilize $\mathrm{K}$ level in order to maintain the normal plasma level.

Ingvartsen et al. [25] recorded a low number of transition cows that showed hypoglycemia with clinical signs of ketosis in their study, with an incidence rate ranged between 0.2 to $8.9 \%$. Also, Fiorentin et al. [26] recorded, in their study in western Santa Catarina, Brazil, an incidence rate of $9 \%$ for the hypoglycemia in dairy cows with a resultant subclinical ketosis. Post parturient septic metritis showed a relatively high incidence rate $(26.81 \%)$ among the investigated disorders during transition period in the studied dairy cows. It is still the main cause of low fertility and delayed conception rates [27]. The innate defense mechanisms of the uterine tissue seek to keep the uterus healthy by reducing the number of pathogenic bacteria. The parturition process itself is considered to be a physical stress that disrupts the endometrial lining, resulting in the invasion of pathogenic microbes [28]. 
Table 3. Classification of dairy cows as normocalcaemic or hypocalcemic in relation to various risk factors on animal level

\begin{tabular}{|c|c|c|c|c|c|}
\hline \multirow[b]{2}{*}{ Variables } & \multicolumn{2}{|c|}{ Calcium level } & \multirow[b]{2}{*}{ P-value } & \multirow[b]{2}{*}{ Odds ratio } & \multirow[b]{2}{*}{$\mathrm{Cl} 95 \%$} \\
\hline & $\begin{array}{c}\text { Normocalcaemic } \\
(n=93)\end{array}$ & $\begin{array}{l}\text { Hypocalcaemic } \\
(n=86)\end{array}$ & & & \\
\hline Breed & & & 0.455 & 0.788 & $0.421-1.474$ \\
\hline Foreign breed & $60(64.5 \%)$ & $60(69.8 \%)$ & & & \\
\hline Mixed native breed & $33(35.5 \%)$ & $26(30.2 \%)$ & & & \\
\hline Age & & & 0.001 & 11.000 & $5.051-23.954$ \\
\hline$\leq 5$ years old & 55 (59.1 \%) & 10 (11.6\%) & & & \\
\hline$>5$ up to 8 years old & $38(40.9 \%)$ & $76(88.4 \%)$ & & & \\
\hline Parity & & & 0.001 & 7.427 & $3.823-14.393$ \\
\hline$\leq 3$ times & $69(74.2 \%)$ & $24(27.9 \%)$ & & & \\
\hline$>3$ times up to 7 times & $24(25.8 \%)$ & $62(72.1 \%)$ & & & \\
\hline Body condition score & & & 0.001 & 0.456 & $0.384-0.540$ \\
\hline$\geq 3.5$ & $72(77.4 \%)$ & $86(100 \%)$ & & & \\
\hline$<3.5$ & $21(22.6 \%)$ & $0 \quad(0 \%)$ & & & \\
\hline Stage of transition period & & & 0.001 & 5.455 & $2.125-14.002$ \\
\hline 3 weeks prior expected day of delivery (EDD) & 27 (29\%) & $6 \quad(7 \%)$ & & & \\
\hline At calving till 3 weeks post-partum & $66(71 \%)$ & $80(93 \%)$ & & & \\
\hline Daily milk yield & & & 0.001 & 0.116 & $0.057-0.237$ \\
\hline High producing $\geq 20 \mathrm{~kg} /$ day & $14(15.1 \%)$ & $52(60.5 \%)$ & & & \\
\hline Low producing $<20 \mathrm{~kg} /$ day & $79(84.9 \%)$ & $34(39.5 \%)$ & & & \\
\hline Previous transition period disorders & & & 0.001 & 0.318 & $0.159-0.630$ \\
\hline Yes & $16(17.2 \%)$ & $52(60.5 \%)$ & & & \\
\hline No & $77(82.8 \%)$ & $34(39.5 \%)$ & & & \\
\hline
\end{tabular}

Table 4. Association between selected serum parameters and the incidence of hypocalcaemia in dairy cows during transition period

\begin{tabular}{|c|c|c|c|c|c|}
\hline \multirow[b]{2}{*}{ Variables } & \multicolumn{2}{|c|}{$\begin{array}{c}\text { Calcium level } \\
\end{array}$} & \multirow[b]{2}{*}{ P-value } & \multirow[b]{2}{*}{ Odds ratio } & \multirow[b]{2}{*}{ Cl $95 \%$} \\
\hline & $\begin{array}{c}\text { Normocalcaemic } \\
(n=93)\end{array}$ & $\begin{array}{l}\text { Hypocalcemic } \\
(n=86)\end{array}$ & & & \\
\hline Phosphorous & & & 0.720 & 1.129 & $0.582-2.191$ \\
\hline$<1.6 \mathrm{mmol} / \mathrm{l}$ & $26(28 \%)$ & $22(25.6 \%)$ & & & \\
\hline$\geq 1.6 \mathrm{mmol} / \mathrm{l}$ & $67(72 \%)$ & $64(74.4 \%)$ & & & \\
\hline Magnesium & & & 0.113 & 1.633 & $0.888-3.003$ \\
\hline$<0.88 \mathrm{mmol} / \mathrm{l}$ & $41(44.1 \%)$ & $28(32.6 \%)$ & & & \\
\hline$\geq 0.88 \mathrm{mmol} / \mathrm{l}$ & $52(55.9 \%)$ & $58(67.4 \%)$ & & & \\
\hline PTH & & & 0.006 & 2.358 & $1.276-4.357$ \\
\hline$<3.15 \mathrm{pmol} / \mathrm{l}$ & $47(50.5 \%)$ & $26(30.2 \%)$ & & & \\
\hline$\geq 3.15 \mathrm{pmol} / \mathrm{l}$ & $46(49.5 \%)$ & $60(69.8 \%)$ & & & \\
\hline Glucose & & & 0.001 & 5.797 & $2.934-11.451$ \\
\hline$<2.62 \mathrm{mmol} / \mathrm{l}$ & $53(57 \%)$ & $16(18.6 \%)$ & & & \\
\hline$\geq 2.62 \mathrm{mmol} / \mathrm{l}$ & $40(43 \%)$ & $70(81.4 \%)$ & & & \\
\hline Potassium & & & 0.019 & 0.483 & $0.261-0.892$ \\
\hline$<4.25 \mathrm{mmol} / \mathrm{l}$ & $44(47.3 \%)$ & $26(30.2 \%)$ & & & \\
\hline$\geq 4.25 \mathrm{mmol} / \mathrm{l}$ & $49(52.7 \%)$ & $60(69.8 \%)$ & & & \\
\hline Sodium & & & 0.001 & 2.672 & $1.460-4.890$ \\
\hline$<196.1 \mathrm{mmol} / \mathrm{l}$ & 57 (61.3 \%) & $32(37.2 \%)$ & & & \\
\hline$\geq 196.1 \mathrm{mmol} / \mathrm{l}$ & 36 (38.7 \%) & $54(62.8 \%)$ & & & \\
\hline Chloride & & & 0.045 & 0.547 & $0.302-0.990$ \\
\hline$<75.5 \mathrm{mmol} / \mathrm{l}$ & 55 (59.1 \%) & 38 (44.2 \%) & & & \\
\hline$\geq 75.5 \mathrm{mmol} / \mathrm{l}$ & 38 (40.9\%) & $48(55.8 \%)$ & & & \\
\hline
\end{tabular}


In the current study, most cases had post parturient septic metritis and first suffered retained fetal membranes. Retained placenta, a multifactorial problem, is frequently seen in recently calved cows. The incorrect intervention in such cases without hygienic considerations is the main factor contributing to the occurrence of post parturient septic metritis as a consequence [29]. The incidence of post parturient septic metritis, including retained placenta was $21 \%$ from records of 97,318 cows in the USA [30]. Furthermore, the incidence of clinical mastitis was $18.99 \%$ in the studied dairy cows. Previous works addressed nearly similar percentages as the overall prevalence of clinical mastitis was $12.0 \%$ in Ecuador [31], 11.5\% in India [32], and $12.5 \%$ in Ethiopia [33]. However, a lower incidence rate of 3 $\%$ was estimated in Chinese study [33].

Generally, the occurrence of multiple disorders was a common feature of the current study. Several epidemiological studies discussed the association between a diagnosed metabolic disorder and a developed inflammatory condition. The acute phase response during the transition period causes alteration of liver function that in turn affects the metabolic pathway. The inflammatory phenomenon during this critical period, triggered by pro-inflammatory mediators and eicosanoids, may affect the dry matter intake. Thus, it is envisaged that a vigorous immune response during the periparturient period may predispose cows for the development of secondary metabolic disorders and vice versa [24]. In fact, it is somewhat surprising to discover the condition that led to the other. The results of this study showed that the cows with hypocalcaemia were found to cause other concurrent diseases in an important way.

Hypocalcaemia is regarded as a gate way disease that predisposes cows to various metabolic disorders and infectious diseases, including metritis, mastitis, abomasal displacement, and reproduction disturbances [34]. Sordillo et al. [35] showed that cows with low serum Ca level are eight times more vulnerable to develop mastitis than those with normal levels. Hypocalcaemia leads to a marked loss of proper skeletal muscle tone, which weakens the rate of contraction and the strength of smooth muscle tissue in the teat canal sphincter. Therefore, a partially opened teat canal will expose the mammary gland to both environmental and contagious pathogens. Furthermore, the downer cow condition caused by a neglected recumbent case of hypocalcaemia will facilitate invasion of environmental mastitis pathogens [6]. Immune cells are very sensitive to the level of $\mathrm{Ca}$ in blood and react accordingly. Intracellular $\mathrm{Ca}$ level is a common messenger for many immune cell receptor mediated response that will be initiated with inflammatory conditions. Insufficient levels of $\mathrm{Ca}$ in blood will disrupt the normal function of the immune system that in-turn open the way to contract not only mastitis, but also other infectious diseases, such as endometritis, placentitis, pododermatitis, pneumonia, and laminitis [36].
For the assessed risk factors for hypocalcaemia on farm level, TMR had a greatest impact on the prevalence of hypocalcaemia in comparison with the NRC system. For ensuring a high productive performance and energy utilization, cows endure extensive loss of their metabolic reserve that should be coupled with increased dry matter intake. The TMR regimen follows the popular line of feeding systems, including a mixed diet of $3-5 \mathrm{~kg}$ of concentrated ration plus green fodder intake without any considerations for the metabolic status and the need for Ca for cows at every stage of transition period. On the contrary, pre-formulated ration considering the NRC recommendations and diet analysis with periodical application of metabolic profile tests in a farm, will surely provide an accurate assessment of the metabolic requirements during each stage of transition period, thus anticipating the problem at a time as early as possible [6]. Furthermore, indoors housing system was significantly associated with hypocalcaemia on farm level. The solar radiation in indoors and / or outdoors hosing system is essential requirement for normal production of vitamin $D_{3}$ from the 7-dehydrocholesterol in skin. The active metabolite of vitamin $D_{3}$ is an essential mediator in the mechanism of $\mathrm{Ca}$ homeostasis in the body, which increases $\mathrm{Ca}$ absorption from the intestine and stimulates Ca re-absorption by kidneys [37].

Concerning the investigated risk factors for hypocalcaemia on cow level, age played a profound role in susceptibility of cows to such condition. Incidence of hypocalcaemia is mostly increased by age, where cows aged between five to ten years are the most commonly affected group [11]. Both vitamin D and PTH are the chief players in $\mathrm{Ca}$ homeostasis mechanism. A decrease in the number of vitamin $D$ receptors in the intestine has been reported with increasing age of the cows [38], as well as the PTH receptors in the target tissues [39]. Likewise, the condition of increased incidence of hypocalcaemia with increased the parity times is related to depletion of resources of $\mathrm{Ca}$ homeostasis. Previous studies recorded that hypocalcaemia occurred predominantly from the third to seventh parities [40-43].

The normal BCS at transition period is a vital issue in prevention of hypocalcemia. Ostergaard et al. [44] reported that over-conditioned dairy cows, at calving, are four times more likely to develop hypocalcaemia. The higher BCS is usually associated with a higher milk yield and thus a higher Ca output, making it more prone to hypocalcemia. Furthermore, over-conditioned cows have a reduced feed intake at peri-calving period compared to thinner cows, and thus a reduced intake of $\mathrm{Ca}$ will predispose for the development of such condition [16].

The occurrence of hypocalcaemia is greatly influenced by the time factor related to the parturition, which is a significant finding of the current study. The Ca concentration in the serum usually reaches a basal level at approximately 12 to $24 \mathrm{~h}$ after parturition [45], as the sudden and severe loss of $\mathrm{Ca}$ in colostrum may reaches a nine fold of its plasma level [6]. In a study performed by Neves et al. (2017), three blood samples were collected to evaluate the concentration of $\mathrm{Ca}$ 
at a weak before, at the onset, and a weak after calving. The results pointed the time as a significant risk factor, as the lowest concentration was expressed at calving day as reported previously by Chapinal et al. [46] and Martinez et al. [47].

The incidence of hypocalcaemia was also associated with higher daily milk production. Many studies have linked the incidence of hypocalcaemia and the high milk production in dairy cows. One possible explanation for this is that cows with high milk production will produce more colostrum, so the $\mathrm{Ca}$ loss will be higher [48]. In an epidemiological study of metabolic disorders in peri-parturient dairy cows, Erb and Grohn [49] reported that cows which experience hypocalcemia at previous parities are two to five times more likely to develop the disease again. Furthermore, Roche and Berry, [41] stated that hypocalcemia is more likely to take place in cows developed the same previous condition by 2.2 times. Likewise, Saborio Montero et al. [43] studied the effect of the previous history of hypocalcaemia in developing a recent condition of the disease, where cows suffered hypocalcemia at earlier calvings were 2.35 times more likely to again experience the event. Surely, hypovitaminosis $D$ and impairment of the parathy-roid function will create a case of hypocalcaemia that differs in clinical degree. Similar to other metabolic diseases, hypocalcaemia may be a result for a primary metabolic or even inflammatory problem that leads to reduction in the daily dry matter intake. Moreover, the abnormal level of beta-hydroxybutyrate in the rumen of ketotic cows was proved to reduce the absorption of $\mathrm{Ca}[6]$.

Serum elements are very sensitive to each other and to what's going around and then, react accordingly. Change in serum $\mathrm{Ca}$ concentration depends largely on other serum elements. During transition periods, the PTH level is fluctuated in response to changes in the Ca homeostasis [6]. In the existing study, the high level of circulating PTH was significantly associated with low $\mathrm{Ca}$ level in blood. Vertebrates developed a highly complex endocrine system mediated by vitamin $D$, the parathyroid hormone and the calcitonin hormone to hold plasma Ca level within normal level. When Ca sensors in the parathyroid gland are sensitized in response to lowered plasma Ca level, the PTH is released to augment the production of the active metabolite of vitamin $\mathrm{D}$ in kidneys, with consequent rapid removal of $\mathrm{Ca}$ from the bones and Ca re-absorption by the kidneys [50]. Vitamin $D$ alone further increases the absorption of Ca from the small intestine. The level of PTH in serum increased greatly at the calving day, and on the $7^{\text {th }}$ day post-partum, as the $\mathrm{Ca}$ level at the specified times was the lowest as compared with the pre-parturient period [13].

Hyperglycemic state was significantly associated with hypocalcaemia in the studied dairy cows. Cows, soon after calving, show a $3-4$ folds increase in plasma glucocorticoid level compared to those at the pre-calving period. But in case of hypocalcaemia, cows exhibit a $5-7$ folds increase in plasma glucocorticoid level at the day of parturition, which may reach up to $10-15$ folds greater as a consequence of metabolic stress. Glucocorticoids soon enhance liver gluconeogenesis, thereby raising plasma glucose level [51].

The serum $\mathrm{Ca}$ concentration showed a significant association with the level of each of $\mathrm{K}, \mathrm{Na}$ and $\mathrm{Cl}$. In the kidneys, Ca calciumis reabsorbed by the proximal convoluted tubule with both $\mathrm{Na}$ and water through mechanisms of passive diffusion and solvent drag. $\mathrm{Na}$ and $\mathrm{Cl}$ ions accumulate inside cells and then are transported into blood stream through basolateral $\mathrm{Na} / \mathrm{K}-\mathrm{ATPase}$. This process resulted in a net cellular re-absorption of both $\mathrm{Na}$ and $\mathrm{Cl}$, with generation of a lumen-positive trans-epithelial potential difference, mediating a non-selective re-absorption of $\mathrm{Ca}$ through the paracellular route [52]. Thus, both hypernatremia and hyperchloremia may be a causative agent for a hypocalcaemia. Furthermore, hypokalemia is considered a metabolic stress on the health status of the cow, which reduces food intake with simultaneous hypocalcaemia.

\section{Conclusion}

Hypocalcaemia is an emerging transition period metabolic disorder, which is likely to occur with other health problems that are largely related to each other and flow from similar sources. It is somewhat unsatisfactory to diagnose metabolic disorders during the transition period based on alarming clinical signs, as owners are aware of many critical demands for nutrients and most metabolic disorders are considered silent. Thus, application of the NRC recommendations, as feeding system, in dairy cows and periodical monitoring of the metabolic profile test in dairy cows during transition period are of paramount importance. It should be taken in consideration that animal risk factors still perceive their impact on the occurrence of hypocalcemia elsewhere, which makes the issue of cows selection criteria applicable to build up control strategies, with the aim of reducing the potential risks of other transition period disorders and improving dairy cattle industry in Egypt.

\section{Conflict of Interest statement}

The authors declare that they have no conflict of interest.

\section{Research Ethics Committee Permission}

All applicable international, national, and/or institutional guidelines for the care and use of animals were followed.

\section{Authors' contribution}

H. S. performed the clinical study and drafted the manuscript, H.I. analyzed the data and revised the manuscript, M.Y. and S.E. revised the manuscript, 


\section{REFERNCES}

[1] Drackley JK. Biology of dairy cows during the transition period: The final frontier? J dairy Sci 1999;82:2259-73. https://doi.org/10.3168/jds.S0022-0302(99)75474-3

[2] Overton T, Waldron M. Nutritional management of transition dairy cows: strategies to optimize metabolic health. J dairy Sci 2004;87:E105-E19. https://doi.org/10.3168/jds.S0022-0302(04)70066-1

[3] Kimura K, Reinhardt T, Goff J. Parturition and Hypocalcemia Blunts Calcium Signals in Immune Cells of Dairy Cattle1. J dairy Sci 2006;89:2588-95. https://doi.org/10.3168/jds.S0022-0302(06)72335-9

[4] Kronqvist C, Emanuelson U, Spörndly R, Holtenius K. Effects of prepartum dietary calcium level on calcium and magnesium metabolism in periparturient dairy cows. J dairy Sci 2011;94:1365-73. https://doi.org/10.3168/jds.2009-3025

[5] Goselink R, Klop G, Dijkstra J, Bannink A. Phosphorus metabolism in dairy cattle: literature study on recent developments and gaps in knowledge. Wageningen UR Livestock Research; 2015.

[6] Constable PD, Hinchcliff KW, Done SH, Grünberg W. Veterinary medicinee-book: a textbook of the diseases of cattle, horses, sheep, pigs and goats: Elsevier Health Sciences; 2016.

[7] Herdt TH. Ruminant adaptation to negative energy balance: Influences on the etiology of ketosis and fatty liver. Vet Clin $N$ AM-Food A. 2000;16:215-30. https://doi.org/10.1016/S0749-0720(15)30102-X

[8] Vazquez-Anon M, Bertics S, Luck M, Grummer R, Pinheiro J. Peripartum liver triglyceride and plasma metabolites in dairy cows. J dairy Sci 1994;77:1521-8. https://doi.org/10.3168/jds.S0022-0302(94)77092-2

[9] Bačić G, Karadjole T, Mačešić N, Karadjole M. A brief review of etiology and nutritional prevention of metabolic disorders in dairy cattle. Veterinarski arhiv. 2007;77:567-77.

[10] Kunz P, Blum J, Hart I, Bickel H, Landis J. Effects of different energy intakes before and after calving on food intake, performance and blood hormones and metabolites in dairy cows. Anim. Sci J 1985;40:219-31. https://doi.org/10.1017/S0003356100025320

[11] Radostits OM, C.C. Gay, Blood DC, Hinchcliff KW. Veterinary Medicine; A Textbook of the Diseases of Cattle, Horses, Sheep, Pigs and Goats,10th Edition. Harcourt Publishers Ltd., Harcourt place, 32 Jamestown Road, London NW1 7BX. UK. 2010.

[12] Shalit U, Maltz E, Silanikove N, Berman A. Water, sodium, potassium, and chlorine metabolism of dairy cows at the onset of lactation in hot weather. J dairy sci 1991;74:1874-83. https://doi.org/10.3168/jds.S0022-0302(91)78353-7

[13] Abd-Allah S, Bakr H. Serum Parathyroid Hormone Levels and Mineral Profiles in High Producing Dairy Cattle Around Calving Period. Br. J. Dairy Sci. 2015;4:1-4. https://doi.org/10.19026/bjds.4.2108

[14] Silanikove N, Maltz E, Halevi A, Shinder D. Metabolism of Water, Sodium, Potassium, and Chlorine by High Yielding Dairy Cows at the Onset of Lactation1, 2. J dairy sci 1997;80:949-56. https://doi.org/10.3168/jds.S0022-0302(97)76019-3

[15] Lean I, DeGaris P, McNeil D, Block E. Hypocalcemia in dairy cows: metaanalysis and dietary cation anion difference theory revisited. J dairy sci 2006;89:669-84. https://doi.org/10.3168/jds.S0022-0302(06)72130-0

[16] Mulligan F, O'grady L, Rice D, Doherty M. A herd health approach to dairy cow nutrition and production diseases of the transition cow. Anim. Reprod. Sci 2006; 331-353. https://doi.org/10.1016/j.anireprosci.2006.08.011

[17] LeBlanc S, Duffield T, Leslie K, Bateman K, Keefe GP, Walton J, et al. Defining and diagnosing postpartum clinical endometritis and its impact on reproductive performance in dairy cows. J dairy sci 2002;85:2223-36. https://doi.org/10.3168/jds.S0022-0302(02)74302-6

[18] Yves P, Louis-Philippe P, D. Robert. Physiology of Small and Large Animals. Endo. Reprod. Fun. 1991:521-6.

[19] Houe H, Østergaard S, Thilsing-Hansen T, Jørgensen RJ, Larsen T, Sørensen JT. Milk fever and subclinical hypocalcaemia--an evaluation of parameters on incidence risk, diagnosis, risk factors and biological effects as input for a decision support system for disease control. Acta Vet. Scand. 2001;42:1-29. https://doi.org/10.1186/1751-0147-42-271

[20] Roche J. The incidence and control of hypocalcaemia in pasture-based systems. Acta Vet. Scand. 2003;97:141-4.

[21] Valk H, Šebek L, Beynen A. Influence of phosphorus intake on excretion and blood plasma and saliva concentrations of phosphorus in dairy cows. J dairy sci 2002;85:2642-9. https://doi.org/10.3168/jds.S00220302(02)74349-X

[22] Caley HK. Grass tetany. Kansas State Univ Agricultural Experimental Station and Cooperative Extension Service MF-976. 1991.

[23] Sweeney RW. Treatment of potassium balance disorders. Veterinary Clinics of North America: Vet Clin N AM-Food A. 1999;15:609-17. https://doi.org/10.1016/S0749-0720(15)30166-3
[24] Trevisi, E., Amadori, M., Archetti, I., Lacetera, N., Bertoni, G.. Inflammatory response and acute phase proteins in the transition period of high-yielding dairy cows: Acute Phase Proteins as Early Non-Specific Biomarkers of Human and Veterinary Diseases. InTech 2011;14: 355-380. https://doi.org/10.5772/20747

[25] Ingvartsen KL, Dewhurst RJ, Friggens N. On the relationship between lactational performance and health: is it yield or metabolic imbalance that cause production diseases in dairy cattle? A position paper. Livest Prod Sci 2003;83:277-308. https://doi.org/10.1016/S03016226(03)00110-6

[26] Fiorentin EL, Zanovello S, Gato A, Piovezan AL, Alves MV, Rocha RX, et al. Occurrence of subclinical metabolic disorders in dairy cows from western Santa Catarina state, Brazil. Pesquisa Veterinária Brasileira. 2018;38:629-34. https://doi.org/10.1590/1678-5150-pvb-5156

[27] Couto G, Vaillancourt D, Lefebvre R. Comparison of a leukocyte esterase test with endometrial cytology for diagnosis of subclinical endometritis in postpartum dairy cows. Theriogenology. 2013;79:103-7. https://doi.org/10.1016/j.theriogenology.2012.09.014

[28] Purohit G, Ruhil S, Khichar V. Postpartum endometritis in dairy cows: current status of diagnosis, therapy and prevention. Theriogenology Insight. 2015;5:1. https://doi.org/10.5958/2277-3371.2015.00001.7

[29] Sheldon I. Bovine endometritis: a review. J Anim Breed. 1999;2:2-14.

[30] Zwald N, Weigel K, Chang Y, Welper R, Clay J. Genetic selection for health traits using producer-recorded data. I. Incidence rates, heritability estimates, and sire breeding values. J dairy sci 2004;87:4287-94. https://doi.org/10.3168/jds.S0022-0302(04)73573-0

[31] Amer S, GÁLVEZ FLA, Fukuda Y, Tada C, JIMENEZ IL, VALLE WFM, et al. Prevalence and etiology of mastitis in dairy cattle in El Oro Province, Ecuador. J Vet Med Sci 2018:17-0504. https://doi.org/10.1292/jvms.170504

[32] Bhat AM, Soodan JS, Singh R, Dhobi IA, Hussain T, Dar MY, et al. Incidence of bovine clinical mastitis in Jammu region and antibiogram of isolated pathogens. Vet world. 2017;10:984. https://doi.org/10.14202/vetworld.2017.984-989

[33] Zeryehun T, Abera G. Prevalence and bacterial isolates of mastitis in dairy farms in selected districts of Eastern Harrarghe Zone, Eastern Ethiopia. J vet med. 2017;2017. https://doi.org/10.1155/2017/6498618

[34] Seifi HA, Kia S. Subclinical Hypocalcemia in Dairy Cows: Pathophysiology, Consequences and Monitoring. IJVST 2018;9:1-15.

[35] Sordillo L, Shafer-Weaver K, DeRosa D. Immunobiology of the mammary gland. J dairy sci 1997;80:1851-65. https://doi.org/10.3168/jds.S00220302(97)76121-6

[36] Kehrli, Marcus E, Nonnecke, J B, Roth, A J. Alterations in bovine neutrophil function during the periparturient period. Am J Vet Res. 1989;50:207-14.

[37] Horst R, Goff J, Reinhardt T. Role of vitamin D in calcium homeostasis and its use in prevention of bovine periparturient paresis. Acta Vet. Scand. 2003;97:35-50.

[38] Horst R, Goff J, Reinhardt T. Advancing age results in reduction of intestinal and bone 1, 25-dihydroxyvitamin $D$ receptor. Endocrinology. 1990;126:1053-7. https://doi.org/10.1210/endo-126-2-1053

[39] Hanai H, Brennan D, Cheng L, Goldman M, Chorev M, Levine M, et al. Downregulation of parathyroid hormone receptors in renal membranes from aged rats. AM J Physiol-Renal. 1990;259:F444-F50. https://doi.org/10.3168/jds.S0022-0302(97)76056-9

[40] Horst R, Goff J, Reinhardt T, Buxton D. Strategies for preventing milk fever in dairy cattle. J dairy Sci 1997;80:1269-80. https://doi.org/10.3168/jds.S0022-0302(97)76056-9

[41] Roche J, Berry D. Periparturient climatic, animal, and management factors influencing the incidence of milk fever in grazing systems. J dairy sci 2006;89:2775-83. https://doi.org/10.3168/jds.S0022 0302(06)72354-2

[42] Reinhardt TA, Lippolis JD, McCluskey BJ, Goff JP, Horst RL. Prevalence of subclinical hypocalcemia in dairy herds. The Vet J. 2011;188:122-4. https://doi.org/10.1016/j.tvjl.2010.03.025

[43] Saborío-Montero A, Vargas-Leitón B, Romero-Zúñiga J, Sánchez J. Risk factors associated with milk fever occurrence in grazing dairy cattle. J dairy sci 2017;100:9715-22. https://doi.org/10.3168/jds.2017-13065

[44] Østergaard S, Sørensen JT, Houe H. A stochastic model simulating milk fever in a dairy herd. Prev vet med. 2003;58:125-43. https://doi.org/10.1016/S0167-5877(03)00049-7

[45] Goff JP. The monitoring, prevention, and treatment of milk fever and subclinical hypocalcemia in dairy cows. The Vet J 2008;176:50-7. https://doi.org/10.1016/j.tvjl.2007.12.020

[46] Chapinal N, Carson M, LeBlanc S, Leslie K, Godden S, Capel M, et al. The association of serum metabolites in the transition period with milk production and early-lactation reproductive performance. J dairy sci 2012;95:1301-9. https://doi.org/10.3168/jds.2011-4724 
[47] Martinez N, Risco C, Lima F, Bisinotto R, Greco L, Ribeiro E, et al. Evaluation of peripartal calcium status, energetic profile, and neutrophil fvunction in dairy cows at low or high risk of developing uterine disease. J dairy sci 2012;95:7158-72. https://doi.org/10.3168/jds.2012-5812

[48] Liesegang A, Eicher R, Sassi M-L, Risteli J, Kraenzlin M, Riond J-L, et al. Biochemical markers of bone formation and resorption around parturition and during lactation in dairy cows with high and low standard milk yields. J dairy Sci 2000;83:1773-81. https://doi.org/10.3168/jds.S0022-0302(00)75048-X

[49] Erb H, Grohn Y. Epidemiology of metabolic disorders in the periparturient dairy cow. J dairy Sci 1988;71:2557-71. https://doi.org/10.3168/jds.S0022-0302(88)79845-8
[50] Aitken p. Metabolic diseases in dairy cows. Vet Times. The website for the veterinary profession. https://www.vettimes.co.uk. 2016. p. 7.

[51] Horst R, Jorgensen N. Elevated plasma cortisol during induced and spontaneous hypocalcemia in ruminants. J dairy sci 1982;65:2332-7. https://doi.org/10.3168/jds.S0022-0302(82)82505-8

[52] Riccardi D, Brown EM. Physiology and pathophysiology of the calciumsensing receptor in the kidney. AM J Physiol-Renal 2009;298:F485-F99. https://doi.org/10.1152/ajprenal.00608.2009 